http://dx.doi.org/10.18778/1505-9057.32.10

Krzysztof Grzegorzewski*

\title{
Opowieści o brzmieniu - o stylu i retoryce w opisach sprzętu audio na lamach czasopisma „Hi-Fi i Muzyka”
}

\section{Charakterystyka czasopisma}

„Hi-Fi i Muzyka” jest miesięcznikiem zaliczanym do kategorii czasopism o tematyce hi-fi - w całości poświęconym zagadnieniom sprzętu służącego do słuchania (rzadziej nagrywania) muzyki. Zawiera recenzje, opisy oraz testy szerokiej gamy sprzętu audio, począwszy od nowoczesnych urządzeń cyfrowych, jak np. odtwarzacze strumieniowe, przetworniki cyfrowo-analogowe (tzw. DAC), soundbary - po wzmacniacze, odtwarzacze płyt analogowych i kompaktowych, kolumny głośnikowe, słuchawki, przewody, a także kompletne systemy hi-fi i hi-end. Jest więc adresowane do odbiorców nie tylko zainteresowanych nowymi technologiami produkcji sprzętu grającego, lecz także cechującymi się dobrze lub wybitnie rozwiniętym zmysłem słuchu, szczególnie wyczulonych na punkcie wrażeń słuchowych (zwanych potocznie ,audiofilami”).

Odrębnym, ale wartym wzmianki zagadnieniem, są gatunki dziennikarskie w czasopiśmie. „Hi-Fi i Muzyka” nie przypomina pod względem układu żadnego typowego czasopisma, np. tygodnika opinii czy miesięcznika. Większość jego łamów zajmują obszerne gatunki publicystyczne', zwane tutaj „testami”, pojawiają się jednak również gatunki znane $\mathrm{z}$ większości tytułów prasowych, tj. edytoriale, wzmianki, notatki, krótkie artykuły informacyjne (tu w charakterze przeglądu nowości sprzętowych), niekiedy sylwetki i - co oczywiste w czasopismach związanych bezpośrednio lub pośrednio z muzyką ${ }^{2}$ - recenzje wydawnictw muzycznych.

\footnotetext{
* Dr, e-mail: krzysztof.grzegorzewski@uni.lodz.pl; Uniwersytet Łódzki, Wydział Filologiczny, Katedra Dziennikarstwa i Komunikacji Społecznej; ul. Pomorska 171/173, 90-236 Łódź.

${ }^{1}$ Rozumienie pojęć gatunków prasowych za: M. Wojtak, Gatunki prasowe, Wydawnictwo UMCS, Lublin 2004; K. Wolny-Zmorzyński, A. Kaliszewski, W. Furman, Gatunki dziennikarskie. Teoria, praktyka, język, Wydawnictwa Akademickie i Profesjonalne, Warszawa 2006.

${ }^{2}$ Podział i systematykę polskiej prasy muzycznej czytelnik znajdzie w publikacji Joanny Mikosz - por. J. Mikosz, Segmentacja polskiej prasy muzycznej, „Acta Universitatis Lodziensis. Folia Litteraria Polonica" 2012, nr 3, s. 147-161.
} 
Kwerenda numerów czasopisma z lat 2012-2015 wykazuje wyraźną przewagę gatunków publicystycznych nad informacyjnymi. Niemal wszystkie teksty mają charakter publicystyczny i perswazyjny - można jedynie obserwować mniejsze lub większe nasilenie tej perswazji (bardziej „,neutralne” pod względem stylistycznym wydają się formy kwalifikowane jako informacyjne, choć i tam obserwuje się świadome użycie chwytów stylistycznych, obcych stylowi informacyjnemu).

Przedmiotem badań prezentowanych w artykule jest styl i retoryka dużych artykułów publicystycznych, tzw. „testów”. Ich struktura jest bardzo do siebie zbliżona i składa się z następujących elementów:

- krótki wstęp wprowadzający w temat (firma, jej produkty i osiągnięcia);

- budowa urządzenia (wygląd, konstrukcja, materiały);

- konfiguracja, w jakiej urządzenia bądź zestawy są testowane;

- wrażenia odsłuchowe;

- konkluzja.

Opis budowy urządzenia nastręcza czytelnikowi zazwyczaj dużo trudności, zarówno z powodu trudnej terminologii, ale także spodziewanego poziomu wiedzy odbiorców. Autorzy nie mogą (i zapewne nie chcą) uniknąć stosowania profesjolektu z zakresu elektroniki czy elektroakustyki. Stajemy zatem przed problemem targetu: do jakich dokładnie czytelników owe testy są kierowane. Można mówić o dwóch możliwościach:

1) zapalony audiofil-amator, tj. pasjonat sprzętu i brzmienia;

2) specjalista zajmujący się w jakikolwiek sposób zawodowo sprzętem grającym, tj. stosujący go w pracy, produkujący w swoich zakładach lub naprawiający w serwisach elektronicznych.

\section{Dźwięk i narzędzia jego opisu}

Zakłada się, że audiofile stanowią grupę dość hermetyczną: są to, jak wspomniano, ludzie o wybitnie rozwiniętym zmyśle słuchu. Ich potrzeby estetyczne w tym zakresie wymagają ponoszenia odpowiednio dużych nakładów finansowych na drodze do ideału: odnalezienia perfekcyjnego brzmienia. Tacy czytelnicy siłą rzeczy muszą się edukować w zakresie elektroakustyki i elektroniki, żeby wiedzieć, na co wydają pieniądze. Początkującemu czytelnikowi używany przez autorów profesjolekt sprawia nieco kłopotu ${ }^{3}$, a często jest także uzupełniany uwagami o charakterze materiałowym, wieloma liczbami i skrótami wyrażającymi

${ }^{3}$ Do takich określeń, często używanych w czasopiśmie, należą choćby: „integra” (zintegrowany wzmacniacz), czy „trafo” (transformator napięcia) „,bufor lampowy”, „kondycjoner”, „dac”, „upsampling”, „technologia MOCVD”. 
poszczególne wartości elektroakustyczne oraz skrótami i wyrazami obcojęzycznymi (na ogół angielskimi). Dużą liczbę określeń profesjolektalnych znajdziemy w częściach artykułów poświęconych budowie oraz konfiguracji.

Kluczową rolę w tekstach pełnią części określane jako „odsłuch” lub „wrażenia odsłuchowe", będące przedmiotem analizy zawartej w niniejszym artykule. W tych właśnie częściach autorzy opisują brzmienie sprzętu i na podstawie swoich wrażeń słuchowych budują konkluzje o charakterze wyraźnej zachęty bądź zniechęcenia do zakupu. Poważnym problemem, jaki przed nimi stoi, jest próba obiektywizacji zjawisk, które - z natury rzeczy - są odbierane wyjątkowo subiektywnie. Wynika to z kilku powodów: indywidualnej zdolności słyszenia, gustu słuchacza, jego nawyków i przyzwyczajeń, rodzaju słuchanej i lubianej muzyki itd. O dźwięku i brzmieniu można pisać w kilku kategoriach, jak: amplituda, dynamika, pasmo przenoszenia (wyrażane w hercach), charakterystyka pasma, określana często jako równowaga tonalna i odstępstwa od niej, a także występujące przy odtwarzaniu zakłócenia. Często jednak mówi się też o separacji kanałów, przestrzeni i panoramie, selektywności i detaliczności dźwięku czy nawet jego gęstości (inaczej: rozdzielczości). To ostatnie pojęcie często wiąże się ze sposobem cyfrowego zapisu dźwięku i jego stosunku objętości do czasu trwania (wyrażonego w kbps), ale może również występować w znaczeniu metaforycznym, rozumianym jako dokładność zapisu - podobnie, jak opisuje się ten parametr w przypadku obrazu. Opis tych parametrów brzmienia będzie jednak dalece niedoskonały z trzech powodów:

1) każdy lubi słuchać inaczej, a wielu zwyczajnie słyszy niewiele;

2) podane wyżej parametry wcale nie przesądzają o lepszych lub gorszych wrażeniach słuchowych;

3) nie oddziałują one na wyobraźnię słuchacza, nie są tożsame z choćby wyimaginowanymi wrażeniami słuchowymi.

Jest więc jasne, że rozpisywanie się o technicznych parametrach dźwięku nie wystarczy - choć te są przywoływane w towarzyszącej tekstowi infografice. Trzeba tu użyć specjalnych środków po to, by te wrażenia sugestywnie i plastycznie opisać. Autorzy tekstów sięgają po wiele narzędzi, jakie oferuje współczesna retoryka, począwszy od rozmaitych figur i tropów stylistycznych ${ }^{4} \mathrm{z}$ metaforą na czele ${ }^{5}$, skończywszy na retorycznych mechanizmach treści ${ }^{6}$, mających budować

${ }^{4}$ Zob. M. Korolko, Przekonuj i daj się przekonać. Dialektyka, retoryka i erystyka z ćwiczeniami, Naukowe Wydawnictwo Piotrkowskie, Piotrków Trybunalski 2003, s. 38; Ćwiczenia z retory$k i$, red. M. Barłowska, A. Budzyńska-Daca, M. Załęska, Wydawnictwo Naukowe PWN, Warszawa 2010, s. 291-329.

${ }^{5}$ Zob. G. Lakoff, M. Johnson, Metafory w naszym życiu, thum. T. Krzeszowski, PIW, Warszawa 1988.

${ }^{6}$ Zjawisko to rozpoznał i zdefiniował Kazimierz Ożóg. Jakkolwiek badacz odnosi je do języka polityki, jest ono przydatne także w badaniach przekazów werbalnych poświęconych innej tematyce. Por. K. Ożóg, Język w stużbie polityki. Językowy ksztalt kampanii wyborczych, Wydawnictwo URz, Rzeszów 2004. 
wspólnotę i porozumienie z czytelnikiem, używanych w celach perswazyjnych. Muszą jednak przy tym brać pod uwagę, że:

- tekst powinien być przynajmniej w tej części bezwzględnie zrozumialy;

- odbiorca może mieć inaczej ukształtowany gust albo inną wrażliwość na dźwięki, więc jego słyszenie nie musi być tożsame ze słyszeniem autora;

- trzeba pisać w taki sposób, by odbiorca mógł sobie owe wrażenia wyobrazić, ponieważ może on nie mieć możliwości odsłuchania sprzętu (odpowiednio skonstruowany opis mógłby być właśnie zachętą do wybrania się do salonu audio);

- odbiorcę trzeba przekonać albo zniechęcić do zakupu uczciwie, abstrahując od względów marketingu i PR (badane w tej analizie teksty nie są sponsorowane) ${ }^{7}$.

Kluczowym celem analizy będzie odpowiedź na pytanie, w jaki sposób autorzy tekstów spełniają powyższe kryteria.

\section{Retoryczne strategie opisywania brzmień w „HI-Fi i Muzyka”}

Szczególnie przydatnym narzędziem pozwalającym wykazać bogactwo stylistyczne artykułów będą wybrane metody retorycznej analizy tekstu zaproponowane przez Jakuba Z. Lichańskiego ${ }^{8}$. Jak zauważa badacz,

retoryka, z czego nie w pełni zdajemy sobie sprawę, jest - podobnie jak media - siłą, która potrafi kreować rzeczywistość. Czyni to poprzez „wikłanie” nas w sieć słów, pojęć, znaczeń, a używa do tego rozumowań. [...] Gdy wkroczyliśmy w fazę cywilizacji medialnej - zaczęliśmy wykorzystywać możliwości oddziaływania na psychikę ludzką i techniki argumentacyjne, jakie tkwią w mediach99.

Owo „oddziaływanie na psychikę” sprowadza się tu przede wszystkim do umiejętnego wywoływania u czytelnika licznych wyimaginowanych wrażeń zmysłowych, odnoszących się do sfery dźwięku - a następnie sprawienia, by ów, pobudzony tymi wrażeniami, zainteresował się podejmowanymi tematami, stale stymulował i rozwijał owe zainteresowania, wreszcie, by podjął określone działania i dokonał konkretnego wyboru. Chodzi tu zapewne nie tylko o dokona-

${ }^{7}$ Uważna lektura czasopism z lat 2012-2015 nie wykazała faworyzowania lub deprecjonowania określonych producentów; ocenie podlegały zawsze jakość oraz brzmienie recenzowanych produktów. Na podstawie tych parametrów budowano argumentację mającą zniechęcić lub zachęcić czytelnika do zakupu, w której istotnym elementem był również stosunek ceny do jakości. Por. G. Habrajska, Naktanianie, perswazja, manipulacja językowa, „Acta Universitatis Lodziensis. Folia Litteraria Polonica" 2005, t. 7, cz. 2, s. 91-125.

${ }^{8}$ J.Z. Lichański, Retoryka a/i media: próba określenia pól wspólnych, [w]: Styl-dyskurs media, red. B. Bogołębska, M. Worsowicz, Wydawnictwo UŁ, Łódź 2010, s. 383-395.

${ }^{9}$ Tamże, s. 389. 
nie zakupu sprzętu audio, lecz także o regularne nabywanie i lekturę kolejnych numerów czasopisma. Temu właśnie ma służyć kluczowy efekt, jaki dziennikarze „Hi-Fi i Muzyka” chcą osiągnąć: skuteczne kreowanie za pomocą retoryki „brzmieniowej rzeczywistości”, w której czytelnik może się niejako „zanurzyć”, wyobrazić ją sobie, odczuć i tym samym niejako usłyszeć.

Spośród zaproponowanych przez Lichańskiego metod można uwzględnić:

- gatunkową - do analizy tekstu jako reprezentanta określonego gatunku (tu: artykułu publicystycznego i/lub recenzji);

- metaforyczną - rozumianą jako analiza aparatu tropologicznego;

- narracyjną - pozwalającą przypatrzeć się tekstom z punktu widzenia teorii narracji;

- noworetoryczną - czyli analizę aparatu argumentacyjnego;

- skojarzeniową - opartą o gotowe skojarzenia i symbole, które mają tworzyć ładunek emocjonalny tekstu ${ }^{10}$.

$\mathrm{Z}$ tej perspektywy mamy w wyżej wspomnianych tekstach do czynienia ze stylem publicystycznym, bogato nasyconym licznymi tropami i figurami, starannie komponowanym pod względem narracji i uzupełnionym sprawną argumentacją. Są to teksty naprawdę ciekawe, zarówno pod względem metaforycznym, jak również konceptualnym. Dziennikarze - m.in. Jacek Kłos, Maciej Stryjecki, Tomasz Karasiński, Mariusz Zwoliński - zdradzają bardzo emocjonalny stosunek do swojego zawodu, ale także do sprzętu, który przysyłają im dystrybutorzy, i oczywiście słuchanej przy jego użyciu muzyki. Przesądza o tym:

- dynamika tekstu (zróżnicowane pod względem konstrukcji i długości zdania, pytania retoryczne, wykrzyknienia);

- przeplatanie stylu wysokiego z potocznym: kunsztowne, bogate i epickie opisy z potocznymi określeniami i frazami, jak np. „co tu dużo gadać” - oczywiście użyte tak, by emocje w odpowiedni sposób wzmocnić i wzbudzić ciekawość odbiorcy, a nie wprowadzić do tekstu niepotrzebny bałagan;

- liczne zwroty bezpośrednie do czytelników, budowanie wspólnoty z nimi, tak potrzebnej później przy wzajemnym „rozumieniu się”, gdy mowa o walorach brzmieniowych;

- wyrażany w tekście osobisty stosunek do słuchanej muzyki, eksponowanie ,ja" mówiącego, swoich brzmieniowych sympatii i antypatii (wyraźnie spersonalizowana narracja).

Liczne elementy tego stylu dostrzegamy np. we fragmencie autorstwa Kłosa:

Audio Research jest poskładany anielsko i nie potrafię mu wytknąć jakiejkolwiek obiektywnej słabości. Więcej, nie potrafię jednoznacznie odpowiedzieć, czy bardziej podoba mi się pięknie zarysowana głębia, naturalnie ciepła średnica czy wzlatujące

10 Tamże, s. 388. 
do nieba harmoniczne, kiedy słucham - i to dopiero paradoks - albumu Diabolus in Musica z muzyką Paganiniego. A może najlepszy jest bas, wypływający z Avalonów gęstą falą? A może wyrównanie w dziedzinie czasu, gwarantujące pełny relaks nawet po nieprzerwanym ośmiogodzinnym odsłuchu? Wszystko jest ważne i wszystko mi się podoba. Klasa bez wymuszania podziwu; dystynkcja bez fochów. Subtelność, siła i zebranie drobnych zalet w piękny spektakl [2012, nr 7-8, s. 65].

Oprócz kunsztu i sprawności retorycznej należy docenić niewątpliwie wysokie kompetencje autorów oraz ich dobry słuch, pozwalający opisać wrażenia brzmieniowe w sposób niezwykle szczegółowy. Pozostaje przyjrzeć się, jaką strategię retoryczną obrali twórcy czasopisma, by swoją wiedzę przekazać.

Metaforyka (rozumiana za Lichańskim jako aparat tropologiczny) jest bardzo bogata i właściwie nie sposób znaleźć artykułu poświęconego brzmieniu pozbawionego metaforyczności. Kolumny ,zasuwają bez utraty tchu” zamiast grać, „dźwięk chętnie opuszcza fizyczne granice obudów” zamiast się wydobywać czy choćby „płynąć” (tendencja do unikania metafor zleksykalizowanych). Bywa i tak, że kolumny „nie znęcają się nad kiepskimi płytami” - choć mogłyby zwyczajnie ,nie brzmieć źle”. Metafor, ale także innych chwytów stanowiących wyrażenia metaforyczne, jest mnóstwo: bywają jedno- i dwuwyrazowe, a niekiedy mają kształt kunsztownych peryfraz. Mogą być wręcz poetyckie: widać to w określeniu głosu Diany Krall jako „miodu doprawionego kropelką whisky” (na jakichś kolumnach autorowi zabrakło tego wrażenia i wytknął ten fakt w tekście). „Zasuwanie” zamiast grania wskazuje na bogate czerpanie z leksyki potocznej, w oparciu o którą także można budować metafory i inne chwyty w sposób bardzo sugestywny.

Wyliczenie i zilustrowanie wszystkich używanych tropów zajęłoby wiele miejsca, choć teksty niewątpliwie stanowią ciekawą podstawę materiałową do analizy metaforycznej. W niniejszym, siłą rzeczy krótkim opracowaniu, lepiej skupić się na sposobach, w jake wykorzystuje się mechanizmy retoryczne dla przekazania czytelnikom wrażeń słuchowych. Z tego punktu widzenia użyte zabiegi można zakwalifikować do następujących kategorii.

Uzmysławianie brzmienia. Wynika ono z konieczności opisania zjawiska, które można jedynie usłyszeć, którego odbiór jest w dodatku szalenie subiektywny, zindywidualizowany, ponadto zależny od indywidualnych możliwości słyszenia. Niezmiernie przydatna okazuje się skojarzeniowa metoda analizy retorycznej tekstu. Ujawnia ona kilka możliwości:

a) wykorzystywanie leksyki odwołującej się bezpośrednio do wrażeń słuchowych: dźwięczeć, brzęczeć, świszczeć, dzwonić, piszczeć itd. „Piszczeć” mogą kolumny, które grają zbyt dużo tzw. „górnej średnicy” (tj. średnio-wysokich tonów) i wysokich tonów; dudni wzmacniacz, w którym charakterystykę przesunięto w kierunku tonów niskich (samo „dudnienie” jest wyrazem ewidentnie 
negatywnie nacechowanym - jak wynika z obserwacji wpisów na forach o tematyce audiofilskiej oraz rozmów ze słuchaczami);

b) epitetowanie z użyciem wyrażeń odnoszących się do pozostałych zmysłów:

- wzroku - rozjaśniony, jasny, błyszczacy i skrzacy się, ciemny, mroczny, pogrubiony, rozmyty, jak np.: „plamy o rozmytych konturach” (pojawiają się tu określenia, takie jak: objętość planu, a więc także zajmowana przez dźwięk przestrzeń; okazuje się ponadto, że dźwięk może przybierać kształty geometryczne, a więc być kragty, kanciasty, a nawet „płaski i kwadratowy”);

- dotyku - szczególnie dużo przymiotników, takich jak: miękki i twardy; gładki i chropowaty; chtodny lub ciepty (nasuwający skojarzenia ze wzmacniaczem lampowym); otulający, lekki, ciężki, rzadki lub gęsty (np. „nagrania Dream Teather są tak gęste, że można by je kroić nożem");

- węchu i smaku - występujące w niewielkiej, ale dostrzegalnej ilości (,miód podlany kropelką whisky”; „lampowa słodycz w najlepszym wydaniu”);

c) epitetowanie z użyciem wyrażeń opisujących cechy fizyczne przedmiotu: głęboki, plytki, rozciagnięty, zwarty, plynny, jedwabisty (,bez zapiaszczenia i metalicznego nalotu"), ale także: drewniany, suchy, sterylny, czysty lub brudny (autorzy korzystają tutaj z całego repertuaru wyrażeń, których może użyć badacz-przyrodnik opisujący materię ożywioną lub nieożywioną);

d) epitetowanie z użyciem cech pozazmysłowych, abstrakcyjnych lub wartości odnoszących się do człowieka: dźwięk bezpośredni, konkretny, rzeczowy, przekonujacy, kontrolowany, ale także finezyjny czy wyrafinowany.

Repertuar wymienionych środków uzmysławiających dźwięk ma pomóc czytelnikowi wyobrazić sobie, jak dany zestaw hi-fi lub jego elementy mogą brzmieć. Czytając specjalny numer z kwietnia 2013 roku zawierający testy 97 par słuchawek, czytelnik natknie się na określenie „gumowy bas”. Chodzi tu zapewne o uchwycenie kilku parametrów, takich jak czystość danego dźwięku, jego atak i wygłos, barwa oraz relacja do innych częstotliwości w nagraniu. Niemniej czytelnik może sobie wyobrazić tępą, nie zawsze przyjemną w dotyku gumową powierzchnię. Autor użył tej metafory w celach wartościujących, a konkretnie: deprecjacji.

Animizacja dźwięku. Potrafi on zachować się jak istota żywa: szybuje, wiruje, uderza rytmicznie, wychodzi na boki albo przed linię łączącą kolumny. Dźwięk może się również „wypełniać” bądź spłaszczać, zmieniać swój kształt i położenie, zajmować większe lub mniejsze fragmenty przestrzeni. Interesujący jest szereg określeń ilustrujących ruch, jak np.: sunać ociężale, pędzić. Animizację znakomicie ilustruje cytat: „Bas w znacznej mierze odpowiada za spektakularną rytmiczność. Jest szybki, zwinny jak kociak, ale kiedy trzeba, potrafi bez ociągania zejść nisko i wydać z siebie groźny pomruk" [2012, nr 7-8, s. 70]. Ta peryfraza nasuwa porównanie tonów niskich z groźnym, drapieżnym kotem (lwem, panterą, tygrysem itd.). 
Innym przykładem - w tekście Stryjeckiego - może być sam tytuł artykułu o zestawie marki TAD za 661 tys. zl: Diamentowy kameleon [2012, nr 7-8, s. 72]. Głównymi cechami tego niezwykle drogiego zestawu mają być więc: wykonanie (szlachetność i piękno, ale również twardość i precyzja) oraz przede wszystkim charakter brzmienia, który zmienia się diametralnie w zależności od odtwarzanego materiału muzycznego. Wynika to jasno z opisu samego sprzętu, ale także wrażeń odsłuchowych, które przyrównano do biologicznych cech kameleona.

Antropomorfizacja dźwięku i/lub sprzętu. Niejednokrotnie zdarza się, że wzmacniacze lub kolumny „coś proponują” słuchaczowi. Kolumny FS428 m-ki ELAC „starają się przekazać tylko to, co zapisane na płycie”, stając się w ten sposób podmiotem w komunikacji ze słuchaczem. Do tego „nie znęcają się nad kiepskimi płytami”. Uosobionemu sprzętowi zwyczajnie przypisuje się intencje, czyny i podejmowane działania - nie tylko w stosunku do człowieka, ale także wobec innych elementów toru (kable względem głośników, wzmacniacze względem kolumn), a nawet wobec płyt. Okazuje się także, że kolumny mogą mieć swoje własne uczucia, stany psychiczne i emocje, bo np. „grają wszystko bez marudzenia”. W innym artykule „JBL-e ochoczo wzięły się do roboty i pokazały, na czym powinien polegać rockowy spektakl. Ich uwadze nie umknęło nic ze stroboskopowych popisów gitarzysty Johna Petrucciego" [2012, nr 7-8, s. 49].

Wspomniany superdrogi zestaw TAD zawiera kolumny, których „dawka bezpośredniości jest najbardziej dobitna, gdy siedzimy na kanapie pośrodku pokoju. Jednak głośniki zachowują się także hojnie wobec naszych gości i nawet ci siedzący gdzieś w kącie na zydelku dostaną 80\% dobrodziejstwa" [2012, nr 7-8, s. 80]. Wspomniany „kameleon” zachowuje się w zależności od włożonego nagrania bardzo różnie: ,jeśli jest płaskie i hałaśliwe, sprzęt tak je zagra. Jeśli przeciętne - zabrzmi przeciętnie. Jeśli będzie wybitne - zaczyna się odkrywanie nowej jakości, dotąd nieznanej. Posiadacza TAD-a czeka też brutalny pojedynek stereotypów z rzeczywistością" [2012, nr 7-8, s. 81].

„Osobowośćc (charakter) dźwięku. Wynika to bezpośrednio z kategorii 2 i 3, w których omówiono środki, służące przypisaniu brzmieniom określonych czynności wykonywanych wobec słuchacza. Dźwięki mogą więc ukotysać, drażnić, pobudzać, atakować - ale te metafory są stosunkowo banalne. W tekstach „Hi-Fi i Muzyka” pojawiają się jednak środki bardziej wyrafinowane, opisujące zachowanie dźwięków wobec człowieka, sposób ich prezentowania się, a nawet swoiście pojęty charakter, niekiedy wręcz „osobowość” - choć jak wszędzie, rozumianą metaforycznie. Brzmienia lub nawet ich elementy stają się wręcz podmiotami mającymi swój własny wygląd, charakter i wizerunek. Jeden z autorów recenzji słuchawek tak pisał o modelu Sennheiser MM 70i: „Bas jest odrobinę pogrubiony, średnica ciut wycofana, za to góra... poezja. Czysta, błyszcząca, elegancka i wcale nie agresywna" [2013, nr 3-4, s. 41]. W opisywanym przypadku charakterystyka jest szczegółowa: zakłada, że poszczególne części pasma zacho- 
wują się inaczej. Przypomina to opisywanie charakteru i zachowania człowieka, które również odznacza się złożonością.

Więcej przykładów takiego „podmiotowego” traktowania brzmienia czytelnik znajdzie w numerze 3-4 z 2013 roku, poświęconym w całości testom słuchawek, np.: „Jeżeli potrzebujecie wyczynowej [...] dynamiki, sięgnijcie po SRH550DJ. Ale jeśli chcecie mieć o wiele wygodniejsze, bardziej kulturalne słuchawki, wybierzcie SRH440” (Shure) [2013, nr 3-4, s. 41]. Słowo „kulturalne” odnosiło się do dźwięku. Słuchawki mogą też powodować zakłopotanie słuchacza: budują przestrzeń, w której czytelnicy poczują się zagubieni. Jak widać, te czynności, działania, a nawet całe strategie podejmowane wobec człowieka moga być wyrafinowane. Niekiedy w opisach sprzętu audio pojawia się nałożenie animizacji oraz antropomorfizacji. Konkretny wzmacniacz lub para słuchawek może mieć swój własny, całkowicie odrębny zestaw cech, który nadaje im wręcz swoiście pojmowaną „osobowość”. Osobowość ta wyłania się zazwyczaj po lekturze całego tekstu.

Warto jeszcze przyjrzeć się retorycznym mechanizmom treści stosowanym przez autorów czasopisma. Opisywanie dźwięku i brzmienia - zjawiska ulotnego, subiektywnego w odbiorze, a jednocześnie budzącego, jak wykazano, ogromne emocje - wymaga przynajmniej próby stworzenia wspólnoty między nadawcą a odbiorcą tekstu. Po lekturze tekstów można stwierdzić, że ich autorzy takie próby podejmują. Dowodem są np. zwroty bezpośrednie do czytelników (na ogół w 2 os. 1.mn.), za pomocą których dziennikarz zachęca, nakłania, odradza, niekiedy zwierza się, pragnie skonfrontować swoje doznania słuchowe z czytelnikami. Niekiedy zwrotom bezpośrednim towarzyszy ironia (nawet sarkazm), jednak sytuacje takie należy zaliczyć do rzadkości. Przykładem złośliwości może być cytat z nr. 7-8 z 2013 roku, w którym Maciej Stryjecki pisze:

Na wstępie tego testu przypominam Państwu, że tanie i przyzwoite stereo to nie miniwieże za 299 zł ani przenośne „empegraje”. To właśnie urządzenia, które przedstawiamy poniżej. Jeżeli macie inne zdanie, kupcie sobie ogrodowy traktorek w supermarkecie, podjedźcie nim na firmowe spotkanie i pochwalcie się, że macie nowy samochód [2013, nr 7-8, s. 19].

Autor w sposób stanowczy broni swojego poglądu i przeprowadzonych testów wzmacniaczy stereo, które znajdziemy poniżej, nieledwie kpiąc sobie z czytelnika, który mógłby mieć inne zdanie. Mógłby być posądzony o złośliwość, gdyby nie fakt, że robi to niezwykle zręcznym stylem. Świadczy o tym przewrotne użycie liczebnika „299 zł” (szyderstwo z zabiegu marketingowego widocznego w marketach), neologizm „empegraje” (kontaminacja skrótu mp3 i augumentativum słowa ,grajek”) oraz zabawny opis sytuacji z ogrodowym traktorkiem w roli nowego samochodu. Wszystko to sprawia, że czytelnik gotów będzie wybaczyć 
autorowi złośliwy ton wypowiedzi i z zaciekawieniem zabierze się do lektury tekstu autorstwa człowieka, który potrafi wyrażać się tak ciekawym językiem.

Niewątpliwie interesującym, wspomnianym już wcześniej mechanizmem jest eksponowanie ,ja" autorskiego, dostrzegalne we wszystkich tekstach tego typu. Testujący sprzęt dziennikarze subiektywizują narrację, piszą o własnych odczuciach, przeżyciach estetycznych i emocjach: zachwycie, zaskoczeniu, rozczarowaniu, rozdrażnieniu itd. Z ciekawością, a nawet zapartym tchem oglądają wnętrza rozkręconych samodzielnie wzmacniaczy lub odtwarzaczy, opisując detale techniczne przy użyciu licznych określeń nacechowanych emocjonalnie, dzięki czemu czytelnik ma wrażenie przeżywania jakiejś przygody, dokonywania wraz z autorem nowych, niesamowitych odkryć. Odczuwa wraz z nim zachwyt, zaciekawienie, ale także irytację lub rozczarowanie. Emocje towarzyszą nawet fragmentom, w których dziennikarz opisuje technikalia, posługując się językiem fachowym. Ułatwia to odbiorcy przebrnięcie przez trudniejsze partie tekstu, w wielu wypadkach pozwala również lepiej je zrozumieć i przyswoić.

\section{Konkluzja}

Materiał badawczy oferowany w „Hi-Fi i Muzyka” jest niezwykle obfity i trudny do analizy. Styl tekstów świadczy o niewątpliwym kunszcie stylistycznym autorów, ale także surowej selekcji materiałów do druku. Wszystkie bez wyjątku artykuły są napisane bezbłędnie, przy czym cechują się bogactwem środków wyrazu. Wychwycenie i zbadanie ich wszystkich wymagałoby wiele pracy, a z drugiej strony czyta się te teksty niemal jednym tchem; nie ma wrażenia przeładowania, przesady - za to jest wyrazista, atrakcyjna i wartka narracja, która naprawdę może być przekonująca. Konkurencyjne pismo „Audio” porusza podobną tematykę stylem poważniejszym, bardziej stonowanym i uboższym retorycznie, co powoduje, że teksty stają się nie tylko bardziej hermetyczne, ale i zwyczajnie nudne.

Analiza strategii retorycznej i użycia adekwatnych do niej środków stylistycznych wykazuje, że cztery cele, które autorzy tekstu muszą mieć na uwadze, są spełnione:

1) teksty, przynajmniej w warstwie opisu dźwięku, są zrozumiałe. Mimo wyrafinowanych metafor, spiętrzonych peryfraz, porównań, zamienni, licznych figur retorycznych (z ironią włącznie) oraz wielu innych środków, autorzy nie pozostawiają wątpliwości, o jakie wrażenia słuchowe im chodzi. Opisy są nie tylko kunsztowne, ale i szczegółowe; wywołują niemal fizyczne doznania. Doskonale również wiadomo, w którym momencie autor zdecydowanie poleca i zachwala, kiedy krytykuje, kiedy się waha (i na czym to wahanie polega), kiedy ma uczucie niedosytu bądź traktuje usłyszane dźwięki z chłodem i dystansem; 
2) odbiorca może mieć inne wrażenia słuchowe niż autor, ale ich obiektywizacji sprzyja używanie leksyki z zakresu akustyki. Wystarczy wiedzieć, co to jest pasmo i jakie są poszczególne jego części, znać kilka podstawowych pojęć z zakresu akustyki i wszystko staje się jasne;

3) użyte sposoby deskrypcji dźwięku, ujęte w niniejszym opracowaniu w czterech kategoriach, zdecydowanie sprzyjają wyobrażeniu sobie brzmienia, o którym piszą autorzy. Najdobitniej świadczy o tym „uzmysławianie” dźwięku, ale również udane próby animizacji, a nawet uosobienia sprzętu oraz generowanego przezeń brzmienia. Dzięki mistrzowskiemu użyciu języka (dynamika stylu, składnia), chwytów stylistycznych, znakomicie wprowadzonych mechanizmów treści, budowania wspólnoty z czytelnikami, nie powinni oni mieć kłopotów z pobudzeniem wyobraźni i niejako „usłyszeniem” wrażeń, które autorzy chcą im przekazać;

4) stosowane w tekstach wartościowanie - niekiedy negatywne, niekiedy pozytywne - wyraźnie świadczy o tym, że autorzy tekstów chcą być szczerzy z czytelnikami i niekiedy aż nadto bezpośrednio opisują cechy danych produktów, nie pozostawiając wątpliwości, kiedy są one złe, nijakie, dobre lub zgoła znakomite. Ta reguła dotyczy każdego opisywanego w piśmie producenta, bez wyraźnych zaburzeń proporcji, które mogłyby świadczyć o faworyzowaniu lub deprecjonowaniu którejś z marek. Zręczne wplatanie określeń potocznych sprzyja wrażeniu bezpośredniości.

Czasopismo „Hi-Fi i Muzyka” oraz zawarte w nim opisy brzmienia są fascynującą lekturą, wartą polecenia miłośnikom muzyki oraz sprzętu audio. Okażą się jednak interesujące także dla odbiorców poszukujących dobrego merytorycznie i stylistycznie dziennikarstwa, tworzonego przez profesjonalnie przygotowanych dziennikarzy, w pełni świadomych swoich możliwości w zakresie stylistyki i retoryki - a przez to zasługujących w pełni na miano homo rhetoricus. Puentą niniejszego opracowania może być fakt, iż jego autor zdecydował się zakupić jeden z polecanych w czasopiśmie wzmacniaczy wyłącznie na podstawie recenzji.

\section{Bibliografia}

Ćwiczenia z retoryki, red. M. Barłowska, A. Budzyńska-Daca, M. Załęska, Wydawnictwo Naukowe PWN, Warszawa 2010.

Habrajska G., Nakłanianie, perswazja, manipulacja językowa, „Acta Universitatis Lodziensis. Folia Litteraria Polonica” 2005, t. 7, cz. 2, s. 91-125.

Korolko M., Przekonuj i daj się przekonać. Dialektyka, retoryka i erystyka z ćwiczeniami, Naukowe Wydawnictwo Piotrkowskie, Piotrków Trybunalski 2003.

Lakoff G., Johnson M., Metafory w naszym życiu, tłum. T. Krzeszowski, PIW, Warszawa 1988.

Lichański J.Z., Retoryka a/i media: próba określenia pól wspólnych, [w]: Styl-dyskurs - media, red. B. Bogołębska, M. Worsowicz, Wydawnictwo UŁ, Łódź 2010, s. 383-395. 
Mikosz J., Segmentacja polskiej prasy muzycznej, „Acta Universitatis Lodziensis. Folia Litteraria Polonica" 2012, nr 3, s. 147-161.

Ożóg K., Język w stużbie polityki. Językowy kształt kampanii wyborczych, Wydawnictwo URz, Rzeszów 2004.

Wojtak M., Gatunki prasowe, Wydawnictwo UMCS, Lublin 2004;

Wolny-Zmorzyński K., Kaliszewski A., Furman W, Gatunki dziennikarskie. Teoria, praktyka, język, Wydawnictwa Akademickie i Profesjonalne, Warszawa 2006.

\section{Krzysztof Grzegorzewski}

\section{Stories about sound. Style and rhetoric in the descriptions of audio equipment in the periodical "Hi-FI i Muzyka"}

\section{(Summary)}

The paper is dedicated to Hi-Fi magazines. The author offers a stylistic analysis of selected texts taken from "Hi-FI i Muzyka" (magazines from the 2012-2014 period), focused on specific types of columns: tests of audio equipment (amplifiers, CD players, gramophones, loudspeakers, etc). The article contains a short description of the magazine and its content, then author has suggested stylistic tools for describing sound (ordered in categories) and offered an analysis with citations.

Keywords: journalism, music, magazines, specialist press, hi-fi, audio, rhetoric, stylistics, persuasion. 